\title{
SIKAP DAN PERILAKU MASYARAKAT TERHADAP HUTAN DI KAWASAN TNKS KECAMATAN GUNUNG TUJUH KABUPATEN KERINCI
}

\author{
Yunita Sri Mayanti ${ }^{1}$, Syafri Anwar ${ }^{2}$, Widya Prarikeslan ${ }^{2}$ \\ Program Studi Geografi \\ Fakultas Ilmu Sosial Universitas Negeri Padang \\ Email : yunitasrimayanti@yahoo.co.id
}

\begin{abstract}
ABSTRAK
Penelitian ini bertujuan untuk mengetahui tentang sikap dan perilaku masyarakat terhadap hutan di kawasan TNKS Kecamatan Gunung Tujuh Kabupaten Kerinci. Jenis penelitian ini adalah penelitian kualitatif. Subjek penelitian ini adalah dinas kehutannan, tokoh masyarakat dan kepala desa yang berjumlah 13 orang. Teknik pengumpulan data yang digunakan adalah observasi, wawancara, dan dokumentasi. Analisis data meliputi reduksi data, penyajian data, dan penarikan kesimpulan. Hasil penelitian ini menemukan bahwa: (1) Sikap Masyarakat terhadap Perlindungan Hutan di Kecamatan Gunung Tujuh Kabupaten Kerinci: a) Masyarakat di Kecamatan Gunung Tujuh sudah melakukan kegiatan reboisasi, b) Masyarakat Kecamatn Gunung Tujuh setuju apabila seperti diadakannya penyuluhan pelestarian hutan dan masyarakat Kecamatan Gunung Tujuh melaksanakan anjuran tersebut, c) Masyarakat di Kecamatan Gunung Tujuh menegur apabila melihat tetangga merusak ekosistem hutan, (2) Perilaku Masyarakat terhadap Hutan Lindung untuk Perambahan Hutan di Kecamatan Gunung Tujuh Kabupaten Kerinci: a) Masyarakat di Kecamatan Gunung Tujuh telah melarang apabila ada dari anggota masyarakat yang melakukan pembukaan lahan baru, b) Masyarakat Kecamatan Gunung Tujuh masih terdapat yang melakukan penebangan pohon dan masyarakat bermata pencarian sebagai petani pada Kecamatan Gunung Tujuh sudah melakukan kegiatan tebang pilih dalam pengambilan pohon pada kawasan Taman Nasional Kerinci Seblat, c) Masyarakat Kecamatan Gunung Tujuh masih terdapat masyarakat yang membuang benda-benda yang dapat merusak kawasan TNKS.
\end{abstract}

Kata Kunci : masyarakat, sikap, perilaku, hutan

ABSTRACT

This study aims to find out about the attitudes and behavior of people on forests in the area TNKS Gunung Tujuh District Kerinci. This type of research is qualitative research. The subjects of this research are dinas kehutanan, community and village head, amounting to 9 people. Data collection techniques used are observation, interview, and documentation. Data analysis includes data reduction, data presentation, and conclusions. The results of this study found that: (1) Public Attitudes towards Forest Protection in Gunung Tujuh District Kerinci District: a) Communities in Gunung Tujuh District have done reforestation activities, b) Gunung Tujuh Kecamatn community agreed if such as the counseling of forest conservation and community of Gunung Sub Seven implement the recommendation, c) Communities in Gunung Tujuh sub-district admonish to see neighbors damaging forest ecosystem, (2) Community Behavior on Protection Forest for Forest Exploitation in Gunung Tujuh Sub-district of Kerinci Regency: a) Communities in Gunung Tujuh Sub-district have prohibited if any from community members clearing new land, b) Gunung Tujuh District community still has tree cutting and peoples searching as farmers in Gunung Tujuh subdistrict has been doing selective logging activities in tree collection in Kerinci Seblat National Park, c) Gunung Tujuh sub-district there are still people who dispose of objects that can damage the area of TNKS.

Keyword: Community, Attitude, Behavior, Forest

${ }^{1}$ Artikel ini ditulis dari skripsi penulis dengan judul Sikap dan Perilaku Masyarakat terhadap Hutan di Kawasan TNKS Kecamatan Gunung Tujuh Kabupaten Kerinci periode Maret 2018 dengan Pembimbing I Prof. Dr. Syafri Anwar, M.Pd dan Pembimbing II Widya Prarikeslan, S.Si, M.Si 


\section{PENDAHULUAN}

Hutan adalah suatu kesatuan ekosistem berupa hamparan lahan yang berisi sumber daya alam hayati yang didominasi oleh pepohonan dalam persekutuan alam lingkungannya yang tidak dapat dipisahkan satu sama yang lainnya. (UU RI No. 41 Tahun 1999).

Sumber daya hutan merupakan salah satu ciptaan Tuhan Yang Mahakuasa yang memiliki peranan yang sangat penting dalam menjaga keseimbangan alam di jagad raya ini. Sebab di dalam hutan telah diciptakan segala makhluk hidup baik besar, kecil, maupun yang tidak dapat dilihat dengan mata. Di samping itu, di dalamnya juga hidup sejumlah tumbuhan menjadi satu satuan yang utuh. Hal ini menjadi sumber kekayaan yang dapat dikelola dengan baik, yang dipergunakan untuk membangun bangsa dan negara.

\section{Deforestasi telah}

mengakibatkan kehilangan flora dan fauna yang hidup dan berkembang biak di hutan alam dan juga mengakibatkan fungsi hutan tropika sebagai paru-paru dunia yang dapat menyerap $\mathrm{CO}^{2}$ di udara dan melepaskan $\mathrm{O}^{2}$ menjadi terganggu. Adanya kegiatan perambahan hutan diyakini sebagai salah satu penyebab semakin meningkatnya laju deforestasi di Indonesia.
Kegiatan perambahan hutan disamping merugikan negara dari segi ekonomi, juga sangat merugikan kelestarian ekosistem hutan alam di Kecamatan Gunung Tujuh. Kerugian negara diperkirakan semakin besar karena sampai saat ini penebangan liar masih berlangsung dan sulit dicegah. Sejak tahun 1996, laju deforestasi meningkat lagi menjadi rata-rata 2 juta ha pertahun. Laju kerusakan hutan ini merupakan tercepat di jagat raya (Haryati, 2008). Kerusakan hutan di Kecamatan Gunung Tujuh yang terus meluas dikhawatirkan daerah ini suatu saat akan terjadi bencana alam.

Salah satu penyebab kerusakan hutan adalah adanya perambahan hutan. Masalah perambahan hutan ini sudah menjadi masalah nasional. Beberapa faktor yang menyebabkan masyarakat melakukan perambahan hutan, yaitu faktor ekonomi, faktor pendidikan, adanya sponsor, keterbatasan petugas pengawas hutan, dan lemahnya sanksi hukum.

Peningkatan jumlah penduduk mengakibatkan meningkat pula kebutuhan akan lahan untuk berbagai kepentingan. Kebutuhan yang meningkat ini mengancam keberadaan hutan. Kebutuhan akan lahan yang semakin meningkat mengakibatkan pembukaan lahan hutan semakin meningkat. 
Kabupaten Kerinci seluas 332.814 hektar atau 3328,14 $\mathrm{km}^{2}$. Lebih setengah dari luas wilayah tersebut atau lebih tepatnya 1990,89 $\mathrm{km}^{2}$ merupakan wilayah Taman Nasional Kerinci Seblat dan 1337,15 $\mathrm{km}^{2}$ sisanya digunakan untuk kawasan budidaya dan pemukiman penduduk.

Laju deforestasi setiap tahunnya semakin meningkat. Seperti kasus yang terjadi di areal hutan TNKS yang berada di Kecamatan Gunung Tujuh Kabupaten Kerinci. Hutan yang ada dibuka secara besarbesaran dan dijadikan sebagai lahan perkebunan / pertanian.

Menurut GW Allport (dalam Widyastuti 2014:57) sikap adalah keadaan mental dan saraf dari kesiapan yang diatur melalui pengalaman yang memberikan pengaruh dinamik atau terarah terhadap respon individu pada semua obyek dan situasi yang berkaitan dengannya. Sikap terutama digambarkan sebagai kesiapan untuk menanggapi dengan cara tertentu dan menekankan implikasi perilakunya.

Selanjutnya Krech dan

Crutchfield (dalam Walgito 2003:123), sikap merupakan masalah yang penting dan menarik dalam lapangan psikologi, khususnya psikologi sosial, yang menempatkan masalah sikap sebagai problem sentralnya. Karakteristik sikap terdiri atas: 1) Sikap disimpulkan dari caracara individu bertingkah laku. 2) Sikap ditujukan mengarah kepada obyek psikologis atau kategori dalam hal ini skema yang dimiliki orang menentukan bagaimana mereka mengkategorikan target obyek dimana sikap diarahkan. 3) Sikap dipelajari. 4) Sikap mempengaruhi sikap. Pengukuhan sikap yang mengarah pada satu obyek memberikan alasan untuk berprilaku mengarah pada obyek itu dengan suatu cara tertentu.

Menurut Thoha (2007: 34), perilaku adalah sebagai suatu fungsi dari interaksi antara person atau individu dengan lingkungannya. Setiap manusia berperilaku berbeda satu dengan yang lainnya dan perilaku ini ditentukan oleh masingmasing lingkungan yang berbeda.

Perilaku merupakan aspek penting yang dimiliki oleh seseorang menentukan tindakan pada suatu objek. Perilaku pada dasarnya merupakan kesiapan mental dan kecendrungan merespon untuk dapat bereaksi pada orang, objek atau ide. Perilaku terhadap objek, gagasan atau orang tertentu merupakan orientasi yang bersifat menetap dengan komponen, kognitif, afektif dan prilaku. Sedangkan komponen prilaku terdiri dari kesiapan seseorang untuk bereaksi atau kecendrungan untuk bertindak pada objek. perilaku merupakan perujudan perasaan seseorang serta penilaian terhadap pemahaman dan keyakinan maupun gagasan terhadap suatu objek yang didasarkan pada 
pengetahuan, pemahaman dan keyakinan maupun gagasan terhadap suatu kecendrungan untuk bertindak pada suau objek.

Sifat-sifat manusia dapat dilihat dari perilakunya, untuk itu ada beberapa prinsip dasar manusia yang berhubungan dengan perilaku, seperti dikemukakan oleh (Thoha, 2007: 3645).

1) Manusia berbeda perilakunya karena kemampuannya tidak sama.

Prinsip dasar kemampuan amat penting diketahui karena dengan terbatasnya kemampuan, maka seseorang akan bertingkah laku yang berbeda. Hal ini dilakukan karena keinginan manusia, dimana untuk mewujudkan keinginan tersebut muncullah berbagai perilaku. Perbedaan kemampuan ada yang dianggap disebabkan sejak lahir ada ada pula yang dianggap disebabkan oleh takdir.

Kecerdasan merupakan salah satu aspek yang berpengaruh terhadap tingkah laku seseorang.

2) Manusia mempunyai kebutuhan yang berbeda.

Perilaku muncul didorong oleh serangkaian kebutuhan. Dengan kebutuhan ini menyebabkan seseorang berbuat untuk mencapainya sebagai seuatu objek atau hasil. Kebutuhan seseorang berbeda dengan kebutuhan orang lain. Kadangkala seseorang yang telah berhasil memenuhi kebutuhan yang satu, kebutuhannya akan berubah atau berkembang. Pemahaman kebutuhan yang berbeda dari seseorang ini akan bermanfaat untuk memahami konsep perilaku seseorang.

3) Cara berpikir

Kebutuhan-kebutuhan manusia dapat dipenuhi lewat perilakunya masing-masing. Dalam banyak hal, seseorang dihadapkan dengan sejumlah kebutuhan potensial yang harus dipenuhi lewat perilaku yang dipilihnya. Kekuatan akan mendorong seseorang untuk berperilaku dalam suatu cara tertentu akan menjadi besar, apabila individu tersebut: 1) percaya pelaksanaan kerja pada suatu tingkat yang ia inginkan tersebut memungkinkan, 2) percaya bahwa perilakunya akan mendapatkan hasil dan 3) hasil yang dicapai yang mempunyai nilai.

Dalam undang-undang Republik Indonesia No.41/1999 tentang kehutanan pasal 1 ayat 2, hutan adalah suatu kesatuan ekosistem berupa hamparan lahan berisi sumber daya alam hayati yang didominasi pepohonan dalam persekutuan alam lingkungannya, yang satu dengan lainnya tidak dapat dipisahkan.

Hutan memberikan manfaat yang besar bagi kehidupan manusia, mulai dari pengatur tata air, paru- 
paru dunia, sampai pada kegiatan industri. Pamulardi (1999), dalam perkembangannya hutan telah dimanfaatkan untuk berbagai penggunaan, antara lain pemanfaatan hutan dalam bidang Hak Pengusahaan Hutan, Hak Pemungutan Hasil Hutan dan Hak Pengusahaan Hutan Tanaman Industri.

Sebagai salah satu sumber daya alam yang dapat dimanfaatkan untuk memenuhi kebutuhan manusia, manfaat hutan dapat dibedakan menjadi dua, yaitu manfaat tangible (langsung/nyata) dan manfaat intangible (tidak langsung/tidak nyata). Manfaat tangible atau manfaat langsung hutan antara lain: kayu, hasil hutan ikutan, dan lainlain. Sedangkan manfaat intangible atau manfaat tidak langsung antara lain: pengaturan tata air, rekreasi, pendidikan, kenyamanan lingkungan, dan lain-lain (latifah, 2004).

Dalam Undang-Undang No. 41 tahun 1999 pasal 6, hutan mempunyai tiga fungsi, yaitu fungsi konservasi, fungsi lindung, dan fungsi produksi. Selanjutnya pemerintah menetapkan hutan

\section{METODE PENELITIAN}

\section{Jenis Penelitian}

Jenis penelitian ini adalah penelitian kualitatif. Moleong (2005) mengemukakan penelitian kualitatif adalah penelitian yang dimaksud untuk memahami fenomena tentang yang dialami oleh subjek penelitian misalnya perilaku, persepsi, berdasarkan fungsi pokoknya ada tiga, yaitu hutan konservasi, hutan lindung, dan hutan produksi.

Berikut ini akan dikemukakan beberapa hasil penelitian yang telah dilakukan dilapangan, yang mana penelitian ini telah menghasilkan beberapa kesimpulan yang berkaitan dengan sikap dan perilaku masyarakat terhadap hutan di kawasan TNKS Kecamatan Gunung Tujuh Kabupaten Kerinci, diantara hasil penelitian tersebut adalah:

Hasil Penelitian Agel Vidian Krama (2007) tentang Perilaku Masyarakat Pinggiran hutan terhadap kerusakan taman nasional Kerinci Seblat Kecamatan Gunung Tujuh. Salah satunya ia menjelaskan bahwa perilaku masyarakat terhadap kerusakan hutan.

Hasil Penelitian Niko Sutra (2003 tentang Sikap Masyarakat terhadap Perlindungan hutan (studi kasus di kenagarian Simanau kecamatan Tigo Lurah kabupaten Solok), menyatakan bahwa terdapat hubungan yang signifikan dan positif antara pengetahuan keluarga dan sikap masyarakat terhadap perlindungan hutan. motivasi, tindakan, dan lain-lain, secara holistik dan dengan cara deskripsi dalam bentuk kata-kata dan bahasa pada suatu konteks khusus yang alamiah dan dengan memanfaatkan berbagai metode alamiah. 


\section{Lokasi dan Waktu Penelitian}

Penelitian ini membahas tentang sikap dan perilaku masyarakat terhadap hutan di kawasan TNKS Kecamatan Gunung Tujuh Kabupaten Kerinci. Lokasi penelitian ini yaitu di Kecamatan
Gunung Tujuh Kabupaten Kerinci. Penelitian akan dilakukan sekitar bulan September - Oktober 2017 di sekitar kawasan hutan TNKS Kecamatan Gunung Tujuh Kabupaten Kerinci.

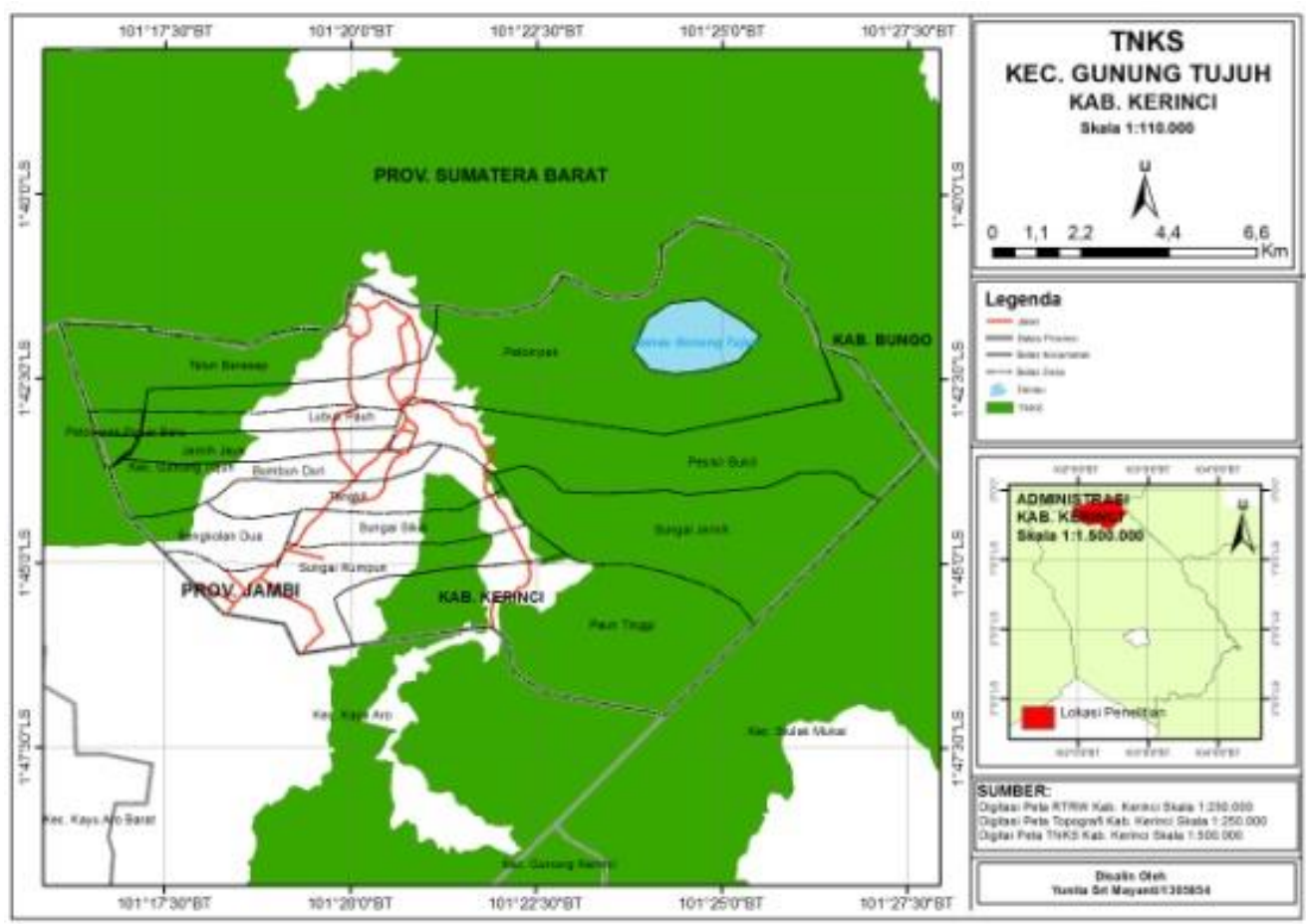

Gambar 1. Peta Lokasi Penelitian

\section{Subjek Penelitian}

Subjek penelitian ditentukan dengan teknik Purposive Sampling, yaitu subjek penelitian ditentukan berdasarkan pertimbangan tertentu. Pertimbangan tertentu ini memuat orang-orang yang dianggap paling tahu tentang apa yang di teliti.

Sehubungan dengan penelitian ini, maka yang akan dijadikan informan penelitian adalah
(13) informan yaitu dinas kehutanan, tokoh masyarakat dan kepala desa.

\section{Tahap-Tahap Penelitian}

Tahap-tahap penelitian yang dilakukan berdasarkan Moleong (2006) adalah sebagai berikut:

a. Tahap Pralapangan

Pada tahap ini kegiatan yang dilakukan meliputi (a) Menyusun rancangan penelitian. (b) Memilih 
lapangan penelitian. (c) Mengurus perizinan. (d) Menjajaki dan menilai lapangan. (e) Memilih dan memanfaatkan informasi. (f) Menyiapkan perlengkapan penelitian. (g) Persoalan etika penelitian.

b. Tahap Pekerjaan Lapangan Pada tahap pekerjaan lapangan ini kegiatan yang dilakukan meliputi beberapa tahap antara lain: (a) Memahami latar penelitian dan persiapan diri. (b) Memasuki lapangan. (c) Mengambil data.

c. Tahap Analisis Data

Pada tahap ini kegiatan yang dilakukan adalah (a) Konsep dasar analisis data. (b) Menemukan tema dan merumuskan hipotesis. (c) Menganalisis berdasarkan hipotesis (Maleong).

\section{Teknik Pengumpulan Data}

Teknik pengumpulan data dalam penelitian ini yaitu sebagai berikut:

a. Wawancara

Wawancara yaitu mewawancarai terhadap informan dilakukan dengan cara tidak berstruktur bebas dan terbuka. Hal ini dilakukan dengan maksud untuk menghindari rasa kaku dan canggung dari informan pada saat wawancara berlangsung, dengan cara yang lebih santai dalam wawancara akan memberikan informasi secara leluasa akan memberikan informasi secara panjang lebar terhadap semua pertanyaan yang diajukan. b. Observasi

Observasi yaitu penelitian merupakan instrumen utama dalam melakukan observasi di lapangan dalam mencari data tentang perilaku masyarakat terhadap hutan di Kecamatan Gunung Tujuh Kabupaten Kerinci. Dalam observasi terdapat hal-hal yang harus dilakukan penelitian yaitu: (a) Observasi umum dengan tujuan untuk memperoleh deskripsi umum tentang situasi sosial yang menjadi objek penelitian. (b) Observasi terfokus tujuannya untuk memperoleh deskripsi yang lebih rinci tentang berbagai komponen atau elemen sebelumnya ditemukan dalam observasi umum. (c) Observasi terseleksi yaitu memilih objek yang lebih terperinci dari sekian banyak komponen atau aspek yang telah diketahui menjadi perhatian utama peneliti.

c. Dokumentasi

Dokumentasi yaitu sangat diperlukan dalam sebuah penelitian dengan maksud lebih mempertajam, memperkuat data hasil yang diperoleh dari lapangan. Kemudian dokumen tersebut dikumpulkan, diteliti ulang dan dianalisis keterkaitannya dengan judul. Dokumen tersebut dapat diperoleh dari berbagai pustaka, seperti diperoleh dari buku-buku, koran, foto, dan arsip-arsip lainnya yang menunjang masalah dari penelitian ini. 


\section{Sumber Data}

Penelitian ini menggunakan dua sumber data yaitu sebagai berikut:

a. Data primer, data ini diperoleh melalui observasi ke lapangan dan wawancara dengan masyarakat.

b. Data sekunder, data ini diperoleh melalui studi pustaka yaitu dari buku-buku, koran, majalah, data statistik, internet yang terkait dan mendukung penelitian ini.

\section{Teknik Analisis dan Keabsahan Data}

Dalam penelitian ini data dianalisis dengan metode yang dikemukakan oleh Miles dan Hubermen yang dikutip oleh Sugiyono (2005) yaitu dengan langkah-langkah sebagai berikut:

a. Reduksi Data (Data Reduction)

Reduksi data merupakan proses pemusatan perhatian pada penyederhanaan, pengabstrakan dan transfomasi data "kasar" yang muncul dari catatan tertulis dilapangan. Reduksi data berlangsung terus menerus selama penelitian berlamgsung. Jadi reduksi data itu adalah bentuk analisis yang menajam, menggolongkan, membuang yang tidak perlu, dan mengorganisasikan data sehingga kesimpulan-kesimpulan akhir dapat ditarik.

b. Penyajian Data (Data Display)

Penyajian data merupakan sekumpulan informasi tersusun yang memberikan kemungkinan adanya penarikan kesimpulan dan pengambilan tindakan, penyajian data dapat berupa matrik, jaringan dan bagan-bagan yang dirancang guna menggabungkan informasi tersusun untuk menentukan kebenaran dalam penarikan kesimpulan.

c. Pengambilan Kesimpulan (Verification)

Penarikan kesimpulan merupakan bagian dari konfigurasi yang utuh. Kesimpulan dilaksanakan selama penelitian, kesimpulan awal bersifat longgar dan akhirnya semakin rinci dan mengakar dengan kokoh. Apabila terjadi kesalahan data yang mengakibatkan kesimpulan tidak sesuai, maka dapat dilakukan proses ulang dengan melalui tahapan yang sama.

Demi terjaminnya keakuratan data, maka peneliti akan melakukan keabsahan data. Dalam keabsahan data ini dilakukan proses triangulasi. Tringulasi adalah membandingkan hasil wawancara dengan hasil pengamatan. Sugiyono (2005) mengemukakan triangulasi dikelompokkan menjadi tiga jenis yaitu triangulasi waktu, triangulasi sumber, dan triangulasi pengumpulan data. Dalam penelitian ini mengunakan metode triangulasi sumber yaitu: peneliti melakukan penelitian ulang serta melengkapi informasi apabila ada informasi yang tertinggal, Selanjutnya juga dilakukan pemeriksaan teman sejawat yang bertujuan untuk 
melihatkan kelebihan atau kekurangan hasil akhir sementara, hal ini dapat dilakukan dalam bentuk tanya jawab. Selanjutya triangulasi

\section{HASIL DAN PEMBAHASAN}

1. Sikap Masyarakat terhadap Perlindungan Hutan di Kecamatan Gunung Tujuh Kabupaten Kerinci

Kawasan Gunung Tujuh yang merupakan salah satu kawasan yang termasuk kedalam zonasi taman nasional. Masyarakat Gunung Tujuh yang mayoritas penduduknya bermata pencaharian petani sejak turun temurun. Mereka menyatakan keberadaan mereka jauh lebih dahulu daripada kawasan Gunung Tujuh dinyatakan sebagai kawasan Taman Nasional Kerinci Seblat.

Berdasarkan hasil wawancara yang telah dilakukan dengan masyarakat di atas, maka terlihat bahwa masyarakat di Kecamatan Gunung Tujuh sudah banyak yang menyadari bahwa pentingnya menjaga kawasan Taman Nasional Kerinci Seblat, oleh karena itu banyak yang ikut serta dalam melaksanakan pelestarian hutan dan melakukan penghijauan. Masyarakat juga menyadari bahwa keberadaan hutan sangat penting untuk kehidupan sehingga menjaganya. Tapi ada juga sedikit masyarakat belum menyadari keberadaan hutan sangat penting untuk kehidupan. dilakukan menurut Dinas Kehutanan, Kepala Desa dan masyarakat di Kecamatan Gunung Tujuh Kabupaten Kerinci.

\section{Perilaku Masyarakat terhadap Hutan Lindung untuk Perambahan Hutan di Kecamatan Gunung Tujuh Kabupaten Kerinci}

Berdasarkan hasil wawancara terkait perilaku masyarakat terhadap hutan lindung untuk perambahan hutan di Kecamatan Gunung Tujuh Kabupaten Kerinci bahwa dalam membuka ladang masyarakat Gunung Tujuh sudah melakukan dengan cara yang benar. Masyarakat disana melakukan pembukaan lahan dengan cara ditebang tidak dengan dibakar. Karena masyarkat takut akan terjadinya kebakaraan hutan.

Masyarakat tidak melakukan pindah-pindah ladang, mereka punya alasan mereka masing-masing tapi mereka hanya melakukan perluasan ladang. Tujuan dari perluasan ladang yang dilakukan oleh masyarakat di hutan tersebut adalah untuk menambah jumlah tanaman yang mereka tanam. Jenis tanaman yang ditanam adalah kopi, kentang, cabe, bawang dan kulit manis. Dan sebagian dari masyarakat Gunung Tujuh masih tedapat yang membuang benda-benda yang dapat merusak kawasan TNKS, seperti membuang sampah pada hutan, berupa sampah plastik, sampah sisa-sisa makanan, sampah botol-botol obat. Kebiasaan 
masyarakat Gunung Tujuh pada umumnya, ketika mereka ke ladang sering kali membuang sampah disembarangan tempat.

\section{PEMBAHASAN}

Berdasarkan data hasil penelitian yang telah penulis lakukan di wilayah penelitian pada tanggal 22 Oktober 2017 sampai dengan 25 Oktober 2017. Daerah penelitian Gunung Tujuh yang diwakili 3 (tiga) Desa, yaitu: Desa Pelompek, Pesisir Bukit, dan Sungai Jernih. Dimana subjek penelitian yang bermata pencaharian sebagai petani pada Kecamatan Gunung Tujuh yang tersebar pada 3 (tiga) Desa. Dengan jumlah informan sebanyak 8 (delapan) orang yang mewakili. Jadi dengan jumlah informan sebanyak yang tersebut di atas, sudah mewakili untuk menemukan jawaban dari penelitian ini.

Data yang penulis kumpulan baik berdasarkan hasil wawancara, observasi ataupun data-data yang diperoleh dari dinas atau instansi terkait, maka hasil analisis mengenai pertanyaan penelitian pada pokok bahasan sebelumnya akan penulis bahas lebih lanjut dalam bentuk uraian berikut:

Pertama: Masyarakat yang bermata pencaharian sebagai petani sudah melakukan yang namanya kegiatan reboisasi, masyarakat menyadari keberadaan pohon pelindung sangat penting pada kawasan Taman Nasional Kerinci Seblat. Berdasarkan hasil penelitian yang telah penulis lakukan, masyarakat yang bermata pencaharian sebagai petani mengemukakan bahwa mereka mengemukakan bahwa mereka melakukan kegiatan seperti tebang pilih, melarang pembukaan lahan baru, dan kegiatan reboisasi karena takut akan ditangkap oleh petugas Taman Nasional Kerinci Seblat serta masyarakat menyadari akan bahaya yang ditimbulkan apabila hutan di sekitar Kecamatan Gunung Tujuh gundul. Masyarakat takut nantinya air pada Danau Gunung Tujuh merembes dan menggenangi pemukiman warga yang tepatnya berada dibawahnya karena dapat mengancam kehidupan masyarakat yang tinggal di kaki Gunung Tujuh.

Dari hasil penelitian di Kecamatan Gunung Tujuh dapat disimpulkan bahwa masyarakat pada tiga Desa yaitu Desa Pelompek, Desa Sungai Jernih dan Pesisir Bukit sudah melakukan kegiatan positif pada kawasan Taman Nasional Kerinci Seblat yaitu: masyarakat telah melakukan reboisasi, masyarakat sudah melarang pembukaan lahan baru, masyarakat juga sudah melakukan tebang pilih dalam pengambilan kayu hutan. Masyarakat yang bermata pencaharian sebagai petani pada umumnya hanya menggunakan lahan mereka yang lama sebagai areal ladang mereka. Sehingga apabila ada diantara mereka yang membuka lahan baru, maka warga masyarakat 
yang bermata pencaharian petani yang lain akan memperingati mereka untuk tidak membuka lahan baru.

Kedua: Perilaku masyarakat dalam penggunaan lahan kawasan TNKS di Kecamatan Gunung Tujuh, tidak ada yang menyebabkan kerusakan terhadap hutan. Karena masyarakat tidak melakukan pindahpindah ladang tapi mereka hanya melakukan perluasan ladang. Cara mereka dalam melakukan perluasan ladang sudah dilakukan dengan baik. Masyarakat melakukan perluasan ladang dengan cara menebang pohon atau semak-semak. Kemudian semak tersebut dibakar. Dalam pembakaran ini masyarakat biasanya menunggu sampai menjadi abu, hasil dari pembakaran tumbuhan ini ditaburkan di atas tanah sehingga bermanfaat untuk kesuburan tanah khususnya untuk tanaman holtikultura. Sehingga perluasan ladang dengan cara seperti ini tidak merusak kesuburan tanah pada lahan yang akan dijadikan ladang baru. Biasanya di Kecamatan Gunung Tujuh yang dilakukan perluasan ladang ini masyarakat menanam jenis tanaman holtikultura dan tanaman lain seperti kopi, kentang, dan cabe. Dan juga masyarakat masih tetap membuang benda-benda seperti sampah makanan, botol pestisida pada kawasan TNKS karena hal itu sudah dianggap biasa oleh masyarakat yang bermata pencharian sebagai petani. Masyarakat pada Kecamatan Gunung Tujuh masih ada yang melakukan penebang pohon pada kawasan TNKS. Hal ini disebabkan karena pada pembangunan rumah mereka menggunakan kayu yang ada pada kawasan TNKS sebagai bahan baku dan dalam pembangunan sarana umum seperti masjid.

\section{PENUTUP}

\section{Kesimpulan}

Berdasarkan hasil penelitian yang dilakukan di lapangan, peneliti dapat menarik kesimpulan tentang Sikap dan Perilaku Masyarakat Terhadap Hutan TNKS di Kecamatan Gunung Tujuh Kabupaten Kerinci dirinci sebagai berikut:

a) Sikap masyarakat terhadap perlindungan hutan di Kecamatan Gunung Tujuh Kabupaten Kerinci umumnya sudah positif, seperti perhatian masyarakat terhadap kelestarian hutan sudah positif, hal ini disebabkan masyarakat sudah menyadari pentingnya akan keutuhan Taman Nasional Kerinci Seblat guna kelangsungan hidup mereka, adapun masyarakat menyetujui apabila diadakan bimbingan tentang pelestarian hutan, masyarakat juga menyetujui bila dilakukan kegiatan reboisasi pada lahan yang sudah gundul di hutan dan masyarakat disana juga menyetujui apabila melihat masyarakat lain merusak ekosistem hutan mereka akan menegurnya.

\section{Saran}

a) Diharap kepada Pemerintah Daerah lebih ketat dalam 
melaksanakan Undang-Undang tentang penebangan pohon supaya tidak ada lagi yang menebang kayu yang berstatus dilindungi di hutan kawasan TNKS Kecamatan Gunung Tujuh Kabupaten Kerinci. Kemudian diharapkan kepada pemerintah juga memberikan penyuluhan serta sosialisasi kepada masyarakat supaya

DAFTAR PUSTAKA

Krama, Vidian A. 2007. Perilaku Masyarakat Pinggiran Hutan terhadap kerusakan taman nasional Kerinci Seblat. Laporan Penelitian Tidak Diterbitkan. Padang: FIS UNP.

Latifah, S. 2004. Penilaian Ekonomi

Hasil Hutan Non Kayu.

http://www.libraryusu.ac.id

[10 November 2017]

Sugiyono. 2011. Metode Pendidikan Kuantitatif Kualitatif dan $R$ \& D. Bandung: Alfabeta

Sutra, Niko. 2003. Sikap Masyarakat terhadap Perlindungan Hutan (Studi Kasus di Kenagarian Simanau Kecamatan Tigo Lurah Kabupaten Solok). Laporan Penelitian Tidak Diterbitkan. Padang: FIS UNP. mereka mengetahui mana kayu yang boleh ditebang.

b) Diharapkan masyarakat tetap menjaga kesuburan lahan atau tanah tempat mereka menanam tanaman. Diharapakan juga supaya masyarakat tidak sering melakukan perluasan ladang. Apabila sering bisa mengganggu keseimbangan ekosistem.

Moleong, Lexi J. 2005. Meotodologi Penelitian Kualitatif. Bandung: Remaja Rosdakarya.

Walgito, Bimo. 2003. Psikologi Sosial (Suatu Pengantar). Ed. IV. Yogyakarta: ANDI.

Sugiyono. (2005). Metode Penelitian Administrasi. Bandung: alfabeta

Widyastuti, Yeni. 2014. Psikologi Sosial. Yogyakarta: Graha Ilmu.

Pamulardi, B. 1999. Hukum Kehutanan dan Pembangunan Bidang Kehutanan. PT RajaGrafindo Persada. Jakarta. 